ligt og kritisk diskuterbart. I uddannelsessystemet bør også den personlige dannelse vægtes, understreger Ferland, og der vil være en vekselvirkning mellem den personlige dannelse og den almene dannelse.

Herudover indeholder samlingen et essay om Samuel Becketts roman Murphy, ét om fremmedord, ét om Roms fysiognomi samt et efterskrift. Trods essaysamlingens tematiske heterogenitet giver den Adorno-inspirerede tilgang samlingen et helhedspræg. Bogen er velskrevet og kan anbefales alle, der er interesserede i Adornos tænkning og kritisk filosofi, der er inspireret heraf.

Klaus Moller Kristensen

\section{Intelligentsia og samfund}

Morten Dyssel Mortensen og Niklas Olsen (red.): Tyske intellektuelle i det 20. årbundrede. Gyldendal, 2005, 324 sider, 299,00 kr.

Hvad er det, der kendetegner en intellektuel, og hvilken rolle spiller de intellektuelle i et moderne samfund? Et par interessant spørgsmål også fra en idéhistorisk vinkel, som måske ikke er sådan lige til at besvare. Lidt nærmere et svar kommer man efter læsningen af antologien Tyske intellektuelle $i$ det 20. arbundrede, hvor en række danske intellektuelle skriver om $i$ alt 20 tyske af slagsen (fra sociologen Max Weber til forfatteren Botho Strauss), hvoraf en lille del stadig lever og virker. En sådan udgivelse fortjener først og fremmest ros som et projekt, der går imod den herskende tidsånd, den stigende tendens i det det danske samfund til at stemple intellektuelle som smagsdommere, eksperter og meningsdannere, dvs. at gøre det at være intellektuel til et skældsord. Det er befriende at få indblik i den tyske lærdomstradition, der især er kendetegnet ved at være grænseoverskridende, forstået på den måde, at de traditionelle faggrænser ikke respekteres. En intellektuel i tysk forstand er både filosof, tænker, forfatter, litterat, samfundsteoretiker - og revser, ja, ofte endda udøvende kunstner.

Det er noget af det, redaktørerne $\mathrm{i}$ indledningen kommer ind på. Her defineres en intellektuel som en der, med "samfundskritisk engagement har været med til at præge den politiske og kulturelle debat" og nok så vigtigt, som en der "forholder sig til nogle helt centrale problemstillinger i det 20. århundredes tyske historie". En sidegevinst ved bogen er faktisk et temmelig fyldigt indblik i Tysklands historie i det 20. århundrede, en på alle måder ekstrem historie, godt ramt med udtrykket: "das Land der Dichter und Denker, Richter und Henker". Når det primære udvælgelseskriterium er aktiv deltagelse i samfundsdebatten, bliver det også umiddelbart mere forståeligt, hvorfor personligheder som Franz Kafka, Georg Simmel, Hans Blumenberg og Reinhart Koselleck ikke er medtaget, bare for at nævne nogle få eksempler (en typisk indvending, som antolo- 
gier ofte bliver mødt med: "Hvorfor er den og den ikke med?").

Både højre- og venstreintellektuelle får tildelt en stemme, og det fungerer faktisk særdeles godt, at Bertolt Brecht og Walter Benjamin befinder sig i selskab med de herrer Carl Schmitt og Ernst Jünger. Det gør det, fordi man som læser derved får serveret et tidsbillede, hvor selvfølgelig de to krige og naziårene danner baggrunden for den erfaring, der prægede generationen født omkring eller i årtierne op til år 1900.

Intentionen med antologien er, som det også står i indledningen "at introducere og stille skarpt på" disse udvalgte intellektuelle, og dette mål må siges at lykkes. Samtlige 20 essays har et højt kvalitetsniveau, og man fornemmer hos alle skribenter en oplagthed $i$ forhold til emnet og den person, de skildrer. De artikler, der fungerer bedst, er de hvor netop overvejelser over fænomenet intellektuel medinddrages, og de, hvor blandingsforholdet mellem liv, værk og gerning hos den pågældende intellektuel fremtræder i det rette blandingsforhold. Sxrligt Per Jepsens Adornoartikel fortjener at blive fremhævet, sammen med Morten Dyssel Mortensen skildring af Thomas Mann og Anne Marie Pahuus beretning om Hannah Arendt. Per Øhrgaard, der både tager sig af Günter Grass og Hans Magnus Enzensberger skriver som altid særdeles veloplagt.

En indvending, man i den forbindelse kunne komme med, er, at gen- nemgangen bliver en smule for homogen, idet de (næsten) alle er præget af en forholdsvis traditionel akademisk skrivemåde. Her falder journalist ved Weekendavisen og tysklandskender Jan Bo Hansens velskrevne artikel om Ernst Jünger lidt udenfor - og det skal forstås positivt! Lidt mere af den slags essayistik med en journalistisk vinkel kunne have fungeret fint.

Man kan undre sig over, hvilken målgruppe, redaktørerne har tænkt sig bogen skulle appellere til, bortset selvfølgelig fra alle, der er lidt mere end bare almindeligt interesseret i tysk kultur og historie i det 20. århundrede. Læst fra ende til anden er bogen lidt af en tour de force og især gennemgangen af forholdsvist komplicerede tænkere som Heidegger og Habermas vil sikkert forekomme den forudsætningsløse, dvs. ikke-akademiske, læser umiddelbart vanskelig, tror jeg. For enhver idéhistoriker må bogen dog være 'gefundenes Fressen', da man, som jeg var inde på før, oplever vigtige tyske tænkere sat ind i en historisk kontekst. Benjamins historiepessimisme, Heideggers egentlighedsfilosofi og Habermas' insisteren på kritisk fornuft og argumenterende samtale forstår man først for alvor betydningen af, når man kender til den tyske virkelighed, der danner baggrunden for deres samtidskritik.

Må bogen varmt anbefales til alle med intellektuelle tilbøjeligheder og med lyst til at vide mere om 'det tyske århundrede'.

Rikke Lonise Peters 